\title{
On a record of Dardanus venosus (H. Milne Edwards) (Crustacea, Anomura) from the São Paulo State, Brazil
}

\author{
Fernando Luis Medina Mantelatto ${ }^{1}$ \\ Renata Biagi Garcia 1, 2 \\ Jussara Moretto Martinelli ${ }^{1}$ \\ Nilton José Hebling ${ }^{3}$
}

\begin{abstract}
The present work is the first report of Dardanus venosus $(\mathrm{H}$. Milne Edwards, 1848) in São Paulo State and extends the range of this species in the western Atlantic farther to the south in the Brazilian region. A total of twenty two males (mean shield length: $7.56 \pm 1.62 \mathrm{~mm}, 4.7$ to $10.9 \mathrm{~mm})$, and fifteen females $(7.25 \pm 2.53 \mathrm{~mm}$, 4.3 to $14.5 \mathrm{~mm}$ ) were collected in $1987,1998,1999$ and 2000 by scuba diving from three areas of Anchieta Island ( $23^{\circ} 33^{\prime} \mathrm{S}, 45^{\circ} 05^{\prime} \mathrm{W}$ ) in the Ubatuba region, and south of São Sebastião Island ( $23^{\circ} 57.8^{\prime}$ 'S $45^{\circ} 16^{\prime}$ W), northern coast of São Paulo State. No ovigerous females were captured during the study period. Shells of eleven gastropod species were occupied by $D$. venosus: Astraea latispina (Philippi, 1844), A. olfersii (Philippi, 1846), A. phoebia Röding 1798, Calliostoma bullisi Clench \& Turner 1960, Chicoreus tenuivaricosus (Dautzenberg, 1927), Cymatium parthenopeum (von Salis, 1793), Olivancillaria urceus (Röding, 1798), Phalium granulatum (Born, 1778), Stramonita haemastoma (Linnaeus, 1767), Strombus pugilis Linnaeus, 1758 and Zidona dufresnei (Donovan, 1823).

KEY WORDS. Brazil, Crustacea, distribution, hermit crab
\end{abstract}

Constant and increasing records of new species and extension of distribution have been reported over the last few years for decapod species in Brazilian waters, principally brachyuran and anomuran crabs, and penaeid shrimps (TAVARES \& MENDONÇA 1996; Rieger \& GiRAldi 1997; MANTElatTo \& Dias 1999). Although there are some obvious reasons for this occurrence, such as the increased number of studies on crustaceans as well as a larger research program focused on marine biodiversity, some questions remain about the origin of these species and how they reached their present locations.

Among the decapod Crustacea, the infraorder Anomura is represented by approximately 800 species in the world and has undergone considerable revision (LANCASTER 1990). Of 46 hermit crab species recorded in Brazilian waters, 20 were registered on the northern coast of São Paulo State, 13 of them belonging to the family Diogenidae (Melo 1999). The genus Dardanus Paulson, 1875 contains a

1) Departamento de Biologia, Faculdade de Filosofia, Ciências e Letras de Ribeirão Preto (FFCLRP), Universidade de São Paulo (USP). 14040-901 Ribeirão Preto, São Paulo, Brasil. E-mail: flmantel@spider.usp.br

2) Curso de Pós-Graduação em Biologia Comparada, FFCLRP/USP.

3) Departamento de Zoologia, Instituto de Biociências, Universidade Estadual Paulista, Avenida 24-A, 1515, Caixa Postal 199, 13506-900 Rio Claro, São Paulo, Brasil. 
fairly large number of species described or ascribed. According to MELo (1999), there are three species on the Brazilian coast: Dardanus insignis (de Saussure, 1858), Dardanus fucosus Biffar \& Provenzano, 1972 and Dardanus venosus (H. Milne Edwards, 1848). The last one is distributed in the western Atlantic: Florida, Bermuda, Antilles, Venezuela, north of South America and Brazil (from Pará to Rio de Janeiro, including Rocas, Fernando de Noronha, Ceará and Rio Grande do Norte). The species occurs from the intertidal zone to a depth of $100 \mathrm{~m}$, and it can be found inhabiting rock, sand, algae, coral, mud or shell bottoms (RIEGER 1997). The species has already been collected and identified from numerous sites in the western Atlantic, and the number of authors describing, or at least citing, this species is quite large (BIFFAR \& PROVENZANO 1972; RIEGER 1997; MELO 1999).

A total of twenty two males (mean, and minimum to maximum shield length - from the tip of the rostrum to the $\mathrm{V}$-shaped groove at the posterior edge: $7.56 \pm$ $1.62 \mathrm{~mm}, 4.7$ to $10.9 \mathrm{~mm}$ ) and fifteen females: $7.25 \pm 2.53 \mathrm{~mm}, 4.3$ to $14.5 \mathrm{~mm}$, were collected in 1987 (May), 1998 (March, July, August and October), 1999 (February, March, May, June, August, September and October) and 2000 (March and April) during daylight sampling by scuba diving. No ovigerous females were collected during the study period. Samples were taken from three areas (North, South and East beaches) of Anchieta Island ( $\left.23^{\circ} 33^{\prime} \mathrm{S}, 45^{\circ} 05^{\prime} \mathrm{W}\right)$ in the Ubatuba region, and south of São Sebastião Island $\left(23^{\circ} 57.8^{\prime} \mathrm{S}, 45^{\circ} 16^{\prime} \mathrm{W}\right)$, northern coast of São Paulo State. These areas present an irregular rocky wall and a non-consolidated sublittoral bottom consisting of gravel and very coarse sand, at a depth of nine meters.

Shells of eleven gastropod species were occupied by D. venosus: Astraea latispina (Philippi, 1844), A. olfersii (Philippi, 1846), A. phoebia Röding, 1798, Calliostoma bullisi Clench \& Turner 1960, Chicoreus tenuivaricosus (Dautzenberg, 1927), Cymatium parthenopeum (von Salis, 1793), Olivancillaria urceus (Röding, 1798), Phalium granulatum (Born, 1778), Stramonita haemastoma (Linnaeus, 1767), Strombus pugilis Linnaeus, 1758 and Zidona dufresnei (Donovan, 1823).

The present work is the first report of this species in São Paulo State and extends the range of this species in the western Atlantic farther to the south in the Brazilian region.

Once a population is successfully established in this region, further dispersal to other areas becomes possible, with consequent adaptation to coexistence with others members of this community (MANTELATTO \& Dias 1999). However, it is not known how the species came there, but probably as extensions of existing Brazilian populations. It is possible that this species was introduced at one or more sites and dispersed via larval stages by the Brazilian current (north-south direction) and subsequent colonization of sheltered sites in Brazil. Another hypothesis is that fishermen tend to select their products in the area before taking them to a commercial landing site, thus consequently introducing new hermit species. All specimens collected are deposited in the crustacean collection of the Biology Department of Faculty of Philosofy, Science and Letters of Ribeirão Preto, University of São Paulo (\# AN-DIO/98/99) and Zoology Department of Bioscience Institute, Paulista State University. 
ACKNOWLEDGEMENTS. FLMM and RBG are grateful to Fundação de Amparo à Pesquisa do Estado de São Paulo (FAPESP, Grant \# 98/07454-5; \# 97/14245-0) for financial support. Special thanks are due to Secretaria do Meio Ambiente do Estado de São Paulo and Parque Estadual da Ilha Anchieta for permission (Proc. \# 42358/98) and facilities during sample work, to Dr. José Carlos de Freitas (University of São Paulo) and Mr. Gilberto Pereira da Silva for collections of some specimens ( $n=7)$ on São Sebastião and Anchieta Islands, respectively, and also to Drs. Osmar Domaneschi (University of São Paulo) and Gustavo A. S. de Melo for shell and hermit species identification, respectively.

\section{REFERENCES}

Biffar, T.A. \& A.J. Provenzano JR. 1972. A reexamination of Dardanus venosus (H. Milne Edwards) and $D$. imperator (Miers), with a description of a new species of Dardanus from the western Atlantic (Crustacea, Decapoda, Diogenidae). Bull. mar. Sci. 22 (4): 777-805.

LANCASTER, I. 1990. Reproduction and life history strategy of the hermit crab Pagurus bernhardus. Jour. mar. Biol. Ass. U.K. 70: 189-238.

Mantelatto, F.L.M. \& L.L Dias. 1999. Extension of the distribution of Charybdis hellerii (A. Milne Edwards, 1867) (Portunidae) along the western tropical South Atlantic. Crustaceana 72 (6): 617-620.

MElo, G.A.S. 1999. Manual de Identificação dos Crustacea Decapoda do litoral brasileiro: Anomura, Thalassinidea, Palinuridea e Astacidea. Ed. Plêiade, São Paulo, 551p.

Rieger, P.J. 1997. Os "ermitões" (Crustacea, Decapoda, Parapaguridae, Diogenidae e Paguridae) do litoral do Brasil. Nauplius 5 (2): 99-124.

Rieger, P.J. \& J.L.B. GiRaldi. 1997. Calcinus tibicen (Herbst, 1791) e Paguristes tortugae Schimitt, 1933, novo registro de Diogenidae (Decapoda, Anomura) para o litoral de Santa Catarina, Brasil. Nauplius 5 (2): 159-161.

Tavares, M. \& J.B. MendonçA JR. 1996. Charybdis hellerii (A. Milne Edwards, 1867) (Brachyura: Portunidae), eighth nonindigenous marine decapod recorded from Brazil. Crustacean Res. 25: 151-157.

Recebido em 23.III.2000; aceito em 19.III.2001. 